\title{
ON THE CONCEPTUAL UNDERPINNINGS OF FAIR VALUE ACCOUNTING
}

\author{
Jatinder P. Singh* \\ Department of Management Studies, Indian Institute of Technology Roorkee, Uttarakhand, India
}

The metamorphosis of business processes and corporate strategies is rapidly progressing across the globe. The critical role of intangibles in corporate performance is receiving its due recognition. Complex tradeable financial products are flooding financial markets. In attempts to gear up for the challenge of financial reporting in this upstaged environment, standard setters have substantively restructured reporting systems, with 'fair value' being the bedrock thereof. Moving away from the traditional 'revenue/expense' matching measure of income towards the 'asset/liability' measure together with the adoption of the Hicksian concept of income is clearly discernible in the pronouncements and ongoing projects of the US Financial Accounting Standards Board (hereinafter referred to as FASB) and the International Accounting Standards Board (hereinafter referred to as IASB ). In this article, an attempt is made to analyze the issues that are controversial and equivocal, or those that need further refinement insofar as fair value accounting is concerned.

Keywords: fair value, financial accounting, 'exit' and 'entry' values, income, conceptual framework, FASB, IASB, asset/liability measure

JEL Classification: G30, M41, N30

\section{INTRODUCTION}

Financial statements prepared under statutes and/ or regulatory pronouncements are invariably mandated to portray a 'true and fair' picture of the reporting entity's financial affairs. Thus, it may either be that such financial statements have, hitherto, presented a 'true and fair' description of

* Correspondence to: J. P. Singh, Department of Management Studies, Indian Institute of Technology Roorkee, 247667 Uttarakhand, India; e-mail: jpsiitr@gmail.com the entity's financial position and performance (whence no radical changes in the regulatory framework were required) or that, paradoxically, provisions or applicable pronouncements have continually been violated. Nevertheless, the paradox is easily resolved. Society is continuously evolving and so is human knowledge and understanding. With this progression, the perceptions and, indeed, the defining characteristics of 'true and fair' are undergoing radical changes. Thus, what has been perceived to be 'true and fair' hitherto 
may not be understood in the same sense hereon. The two defining features of financial reporting are reliability and relevance, with an inter se tradeoff between them dictating the underlying philosophy of all financial reporting models. Hitherto, reliability has been perceived as critically important in financial reporting, leaving relevance relatively unattended. The accounting fraternity worldwide has been obsessed with the ascendancy of 'reliability' over 'relevance'. However, times have moved on and views have changed almost diametrically in the preceding few decades. With the increase in the contribution of intangibles and complex financial products in contemporary business (Boulton, Libert \& Samek, 2000; Eccles, Herz, Keegan \& Philips, 2001; Lev, 2001; Chabrow \& Colkin, 2002), the tradeoff has perceptibly tilted in favor of the 'relevance' of financial reporting to stakeholders and other users (Eckstein, 2004; Uzma \& Singh, 2009a; 2009b). As party to this transition, 'income' characterization has moved back from the 'matching' approach to the 'asset/ liability' approach, signaling a radical shift in the underlying 'conceptual basis of financial reporting'. Furthermore, the appropriateness of associating 'income' with the marketplace by using marketbased valuations is felt immensely desirable by the community, thereby ushering in the era of fair value accounting (FVA).

Financial reporting under the 'fair value' based accounting system states assets and liabilities at their respective current values. Therefore, this accounting system is occasionally called 'mark-tomarket' accounting. Formally, 'fair value' is defined in Accounting Standards Code 820 (FASB, 2009) (formerly SFAS 157; FASB, 2001) of the US and the corresponding IFRS 13 (IASB, 2012), in essence, as 'the price that would be received to sell an asset or paid to transfer a liability in an orderly transaction between market participants at the measurement date.' Nevertheless, the very definition of 'fair value' is beset with controversies and ambiguities. For one thing, accounting standards define the 'fair value' of assets and liabilities conceptually in terms of respective 'exit value', rather than their 'entry value'. This aspect assumes immense significance in environments beset with market frictions and other imperfections. Another critical source of ambiguity and controversy in the contemporary accounting setup that was identified in course of the literature review was the adoption of Hicksian income as its underlying philosophy. However, an equally popular conceptual approach to income measurement is attributed to the noted economist I. Fisher (referred to as Fisherian income) (Rayman, 2007).

This article has the key objective to examine the implications of these issues that have left fair value accounting short of being a perfect accounting framework, rather than a 'panacea for all evils'. Precisely, we explore the ramifications of:

- the paradigm shift of the accounting regulatory bodies to the redefinition of the conceptual basis of reporting from the 'revenue/expense' approach to the 'asset/liability' model;

- the use of 'exit' value in contradistinction to the 'entry' value and the 'value in use' in defining 'fair value';

- the adoption of 'Hicksian' income as the underlying philosophy of income measurement.

This paper's objectives have been attained through a comprehensive and critical study of the conceptual underpinnings of the pronouncements of the accounting regulatory bodies and a detailed review of the relevant research literature.

In line with the study's objectives, the following null hypotheses are set up for evaluation: 
H1: The 'asset/liability' conceptual framework recommended by the FASB and IASB invariably correctly reports the financial affairs of an entity;

H2: The 'exit'-based valuation adopted by the FASB and IASB in the definition of the 'fair value' of assets and liabilities is the appropriate accounting measure of fair value in all circumstances;

H3: The 'Hicksian' concept of 'income', adopted by the FASB and IASB, in conjunction with the 'asset/liability' framework, is essentially the appropriate accounting measure of income;

with the usual corresponding respective alternative hypotheses.

We put these hypotheses to test through a study aimed at analyzing various standards and other pronouncements of the FASB and IASB and their possible impact on the adoption of the 'asset/ liability' framework, the 'exit'-based definition of fair value and the Hicksian concept of income by affected entities.

It is pertinent to point out here that SFAS 157 (FASB, 2001) and several other related standards have been substantively adapted into the Accounting Standard Code (ASC) promulgated by the United States Financial Accounting Standards Board (FASB). This ASC of the FASB constitutes the complete source of the extant authoritative Generally Accepted Accounting Principles (GAAP), recognized by the FASB, to be applied to nongovernmental entities. The ASC is effective for interim and annual periods ending after September 15, 2009. It has been formulated through the comprehensive restructuring and reorganizing of the various pronouncements of the FASB from time to time and now constitutes the sole authoritative diktat of the FASB on the US GAAP, superseding all the erstwhile accounting standards. All accounting literature not explicitly included in the ASC has been declared to be non-authoritative by the FASB.

\section{CONCEPTUAL FRAMEWORKS FOR FINANCIAL REPORTING}

There are two alternative conventional conceptual frameworks underlying the preparation of the financial statements of an entity viz. the 'revenue/ expense' approach and the 'asset/liability' approach (Nissin \& Penman, 2008). Under the former approach, the income statement, which is formulated as a matching of the revenues and expenses relating to the relevant accounting period, is the primary accounting output. It portrays the performance and progress attained by the entity in executing an envisaged business model, whereas the balance sheet is returned as a residual. As such, the value figures in the balance sheet do not and are not intended to reflect the present values of projected future cash flows or other business valuations in any sense. The eventuality of their reflecting such valuations is an idealization bordering on aberration. The accounting standards of and conventions on 'Revenue Recognition' dictate the modus operandi for recognizing and gains. Compliance with the 'matching' principle ensures that expenses and revenues are properly matched and related to the same accounting period.

The balance sheet under the 'revenue/expense' approach constitutes the grouping of residuals. Such residuals arise from timing differences, so that assets are the accounts that are likely to enter into future income statements as and when their consumption actually takes place for producing income/cash flows (in accordance with the 'matching' principle). Liabilities are similarly construed. Most balance sheet accounts, other than those arising on account of revenue recognition, are not market marked. As such, they do not indicate economic values, nor do they represent the present valuations of future cash flows. They are merely the expressions of consumption value as per the business model being pursued by the entity.

In the 'asset/liability' approach, assets and liabilities are the primary elements and are defined 
initially. They form the basis for defining the other accounting elements viz. 'equity', 'income' and 'expenses'. Income for an accounting period equals the change in net assets (apart from transactions with owners). Thus, the emphasis shifts from the income statement (which, now, becomes a collection of residuals) to the balance sheet. The income statement merely presents the changes in valuations between the beginning and the end of the relevant accounting period.

Against the above, the primary merit of the 'revenue/expense' approach propounded by its votaries is that it enables the smoothening out of the volatile effects of certain types of transactions through the mechanism of deferring charges and credits. The 'asset/liability' approach may result in a fluctuating income statement that may include unrealized holding gains and losses (Benston, 2006; Gwilliam \& Jackson, 2008).

Presently, there is an unambiguous perception of the superiority of the 'asset/liability' approach, primarily on account of its following attributes:

- Assets and liabilities are real, usually physical and tangible objects. As such, they are more amenable to actual identification, classification and measurement than the contents of the income statement. The adoption of the 'asset/ liability' approach thus adds to precision in financial reporting.

- The 'causal' flow also advocates the 'asset/ liability' approach. i.e. a change in the value of net assets constitutes the 'cause' and income is the 'effect' thereof, not the other way round.

Of late, the 'asset/liability' approach has found immense favor with the standard setters, in particular with the IASB, as testified by the IASB's Conceptual Framework of 2010 that defines an asset as a 'resource controlled by the entity as a result of past events and from which future economic benefits are expected to flow to the entity' and a liability in the same vein as 'a present obligation of the entity arising from past events, the settlement of which is expected to result in an outflow from the entity of resources embodying economic benefits'. Thereafter, the said framework goes on to define income in terms of the op-defined assets and liabilities as 'increases in economic benefits during the accounting period in the form of inflows or enhancements of assets or decreases of liabilities that result in increases in equity, other than those relating to contributions from equity participants'. Although this transition to the 'asset/ liability' approach is well-received by stakeholders in general, several aspects of the framework need ironing out (Bromwich, 1992; Sunder, 1997; Christiansen \& Demski, 2003; Watts, 2003a; 2003b; Benston, Bromwich \& Wagenhofer, 2006; Sundem, 2007; Benston, 2008; Whittington, 2008; Christiansen, 2010). Appreciating this concern, the IASB has invited comments through the issue of Discussion Paper No. DP/2013/1 in July 2013.

Some proponents of the 'asset/liability' approach perceive the existence of a strong nexus between this approach and the recognition, measurement and carrying of accounts at fair values to the extent that the former implies the latter. This presumption, however, seems questionable, as evidenced by the following counterexamples:

- Consider the situation when a customer makes an advance payment prior to the actual delivery of goods. Most of us would agree that revenue recognition should take place in the accounting period in which the job to which the payment pertains is actually performed. This would be the period in which the payment is earned. Prior thereto, it should be recorded as deferred revenue. In case the job is spread over several accounting periods, we note that the asset that is driving revenue recognition is the job being performed for the customer. As such, revenue should be recognized commensurate with the value enhancement (determined by some appropriate estimation process) of the job. This is analogous to the percentage completion method. 
- An alternative to above would be to recognize revenue on the basis of the entity's satisfaction of its own contractual commitment to transfer the good to the customer. In this model, revenue recognition is driven by the entity's contractual commitment to transfer the good to the customer. This model would yield outcomes similar to the usual 'delivery' models.

- The third choice would be to recognize revenue as and when actual cash is received from the customer. In this case, the cash itself is the asset that drives the revenue recognition process. This, in fact, constitutes the cash basis of accounting.

The above accounting conundrum, along with several others, was deliberated as part of the Joint FASB and IASB Project on Revenue Recognition, completed in June 2014. Intense discussions eventually culminated in the Boards' agreeing to adopt, as the general rule, that revenue shall be recognized by an entity upon its compliance with its contractual obligation to transfer a good or service to the customer. More importantly, however, having established this standard of recognizing revenue commensurate with changes in the value of a liability (i.e. the entity's performance obligation under the contract with the customer), the Boards did not jump forthwith to measuring this liability on the basis of fair value. On the contrary, it was ultimately resolved that the said performance obligation of the entity should be measured by the allocation of the measure of the rights in the contract to all of the identified performance obligations. Thus, in this particular instance, although the 'asset/liability' approach was applied to revenue recognition insofar as revenue recognition was linked to changes in the value of a liability, the measurement of that liability was not prescribed at fair value.

Notwithstanding the above anomaly, not as an imperative consequence of adopting the asset/ liability' approach, but rather as a judicious conscious decision stemming from a desire to make reporting more aligned with economic substance, rather than statistical accuracy, the IASB seems to have made a paradigm shift in order to usher in FVA as rapidly as practicable. It would be in place, therefore, to discuss the conceptual underpinnings of FVA, fair value and the income measurement strategy under FVA (Bromwich, 2001; Dean \& Clarke, 2003; Wells, 2003; Potter, 2005; Dennis, 2006; 2008; Rayman, 2006; AAA, 2007; 2010; Penno, 2008).

\section{THE CONCEPTUAL BASIS OF FAIR VALUE ACCOUNTING}

The cardinal activity in the overall process of financial reporting is, obviously, the value 'measurement' process (Barth, 2007). Two elemental constituents (sub-processes) aggregate to form this measurement activity viz. choosing a suitable measurement base, e.g. the historical cost, fair value at entry (the replacement cost), fair value at exit (net realizable value), value in use etc., and measuring the relevant account in the selected measurement base.

A structured procedure is put in place by the provisions of the US ASC 820 (FASB 2009), which may be regarded as the benchmark in FVA for addressing the latter issue. However, the choice of the measurement base is left open to the discretion of the entity adopting FVA. In other words, ASC 820 (FASB, 2009) gives us the methodology for calculating fair value, on the one hand, but fails to explicitly set out the circumstances in which FVA is to be adopted, on the other. As exceptions to this norm, FVA is prescribed exclusively or as an alternative in the context of some categories of assets in the provisions of several other FASB standards, e.g. SFAS 133 (Accounting for Derivatives \& Hedging Activities; FASB, 2000), SFAS 141 (Business 
Combinations; FASB, 2001), SFAS 142 (Accounting for Intangibles; FASB, 2001) and so forth.

The votaries of FVA cite the following in support of its efficacy:

- Financial statements are primarily used in order to make economic decisions;

- An entity's current and prospective investors and creditors are the reference users of its general-purpose financial reporting. The primary purpose for which these interest groups would use the entity's financial statements is to assess its investment and credit worthiness. For this objective to achieve, they would make suitable future cash flow forecasts. Thus, it would be desirable from this perspective that accounting information, as reported in financial statements, should be aligned with the future to the extent possible, rather than reflect the past. Reporting the information that reflects the past would only serve this purpose if it were indicative of the future and, therefore, useful for making projections. Now, fair valuations encapsulate presentation in terms of the present values of future cash flows.

- The cardinal attribute of financial statements is, now, strongly perceived to be 'relevance', in contradistinction to 'reliability'. Reliability has largely been overshadowed by the attribute of representational faithfulness in the context of financial reporting.

- Prices are believed to give an unbiased assessment of the present values of cash flow forecasts in efficient market conditions. Thus, these figures are based on the economic behavior of the aggregates of market players instead of entity-specific assessments. One may also assume representational faithfulness to be present in contemporary markets on account of high efficiency and completeness.

\section{'FAIR VALUE': 'EXIT' versus `ENTRY' VALUE}

Fundamentally, this issue relates to the relative superiority of the valuation of assets and liabilities for financial reporting at the funds they would generate on sale (current exit value) vis-à-vis the funds necessary for making them available to and ready for the entity to use (current entry value). In a marketplace endowed with pure and perfect competition, with no market frictions, these two measures of value would converge. However, in the presence of significant market frictions, like transaction costs, commissions, transportation costs, etc., the net cash inflows received by the seller are likely to be different from the cash payments made by the buyer. As such, in most real-life situations, the exit value of an asset may be significantly different (usually lower) than its entry value. Before proceeding to an analysis of this issue, we set forth the relative features and virtues of both.

The exit value of an asset is the maximum net amount that can be obtained on the sale/disposal of that asset in the normal course of business (i.e. not in a forced sale) in a short period of time. For this purpose, the net amount represents the sale proceeds less the costs of disposition, on a post-tax basis, discounted to the date of financial reporting/ valuation, as desired.

Precisely, the exit value of an asset determines, in monetary terms, the generalized command over the resources that the accounting entity can attain by selling the relevant asset. The entry value, on the other hand, ascertains the present cost of acquiring the cheapest asset (in the markets in which the entity normally trades) that provides to the entity, services congruent to those that the asset being valued is providing en presenti and is expected to provide in future.

It would seem that exit value would, prime facie, be the more relevant form of asset valuation in the context of bodies corporate on the following premises: 
- The primary objective of bodies corporate is to further the interests of their stockholders;

- Exit valuation would provide information on the amount that can be realized by the entity and distributed to the stockholders through the sale of the relevant asset in the normal course of business;

- The amount so realized and distributed to the stockholders could be used by them to satisfy some of a variety of wants (that they may have) through the expenditure of the distributed proceeds.

Another characteristic that strongly favors exit valuation relates to the computation of return ratios from financial statements. The principle adopted for asset valuation impacts both the denominator (directly as the value of the funds employed) and the numerator (in the form of a depreciation charge) of these ratios. Now, at any point in time, the realistically viable options available to an entity's management are either to 'sell' or 'not sell' the assets it possesses (that are the subject matter of the valuation). Thus, it would seem that the appropriate valuation of such assets would be at the amount for which they could be exchanged (i.e. exit value), rather than the current market price of equivalent assets. Exit value represents the implicit current investment in an asset. Return computed on entry valuation is based on the investment that the entity's management refuses to renounce in exchange for receiving the assets. Entry valuation seems redundant on this count because the action of 'not buying' the asset may not be acceptable whence the return calculated on the basis of entry valuation would tantamount to a performance measure that the entity's management has discretion to refuse. The evaluation of the entity's management through benchmarking against such a measure would amount to evaluating them on the premise of an investment that they might now refuse. However, return computed on exit valuation is based on the investment that the entity's management refuses to accept in exchange for the assets, the base that is relatively fair and equitable.

Let us now look at the numerator of return computation. For facilitating consistency, this should reflect the income generated from the deployment of the assets constituting the denominator. Contemporary theorists prefer to define income (loss) as the surplus (deficit) of the aggregate of the net revenue (before depreciation, but after charging all 'matching' expenses) generated during the relevant accounting period together with the saleable value of the net fixed assets at the end of the said accounting period less the saleable value of the net fixed assets at the beginning of the said accounting period. Equivalently, income (loss) would be the surplus (deficit) of net revenues over the decline in the net saleable (exit) value of the fixed assets over the period. It follows as a corollary that the existence of income is prima facie the testimony of the veracity of the management's decision taken at the beginning of the accounting period in order to continue operations for the accounting period by holding on to the assets because the net cash revenues generated from the use of these assets exceeded the decline in their exit value (depreciation). On the other hand, if an entry-based asset valuation is adopted, depreciation reflects the change in the 'cost of acquisition' of the said assets over the relevant accounting period. The corresponding return ratio is, therefore, built on the premise that the entity's management had the option of retaining the market price of the asset in lieu thereof at the beginning of the accounting period, which, in fact, they never did have. It follows that net income as well as depreciation in the return ratios need to be computed on the basis of exit values so as to enable a meaningful interpretation of such ratios.

On the other hand, the entry value of an asset emphasizes the 'going concern' characteristic of an entity. It assumes the survival of an entity as a 'necessity', for the attainment of which it may need to replace an asset that goes out of commissioning. 
This obligatory replacement would, obviously, involve the acquiring of the equivalent asset at the current market price, i.e. entry value. Thus, in the event that a positive income is returned based on this valuation philosophy, the survival of the entity as a going concern may justifiably be inferred, and vice versa. 'Survival' in this context is also characterized by the entity's ability to replace the used services so that the expense should also be measured by the current acquisition cost (entry cost) of those services. In this scenario, income is not precisely the surplus of the end of the accounting period balance sheet over the one at the beginning of the accounting period. A significant merit of entry valuation is that it facilitates comparability among entities, thereby enhancing the utility of the statements so prepared. The statements would also be indicative of the nature and context of the resources that the entity expects to use in its projected activities. As mentioned earlier, the cardinal application of financial statements is to help make future projections by investors and creditors. In this context, entry valuation would seem to hold an edge over exit valuation, the choice, basically representing the tradeoff between information on the entity's intention (entry) and the entity's flexibility (exit) for the future. The exit valuation of assets that purports to indicate the cash market value of the relevant assets is largely of current interest only, being reflective of the entity's flexibility. Furthermore, such exit valuation is likely to be relatively much less precise as it represents the valuation of the assets in their second or third best use. Anomalous situations may also arise in instances where the expenses of asset disposal exceed the market value of the asset, resulting in negative exit valuations.

At this point, it is necessary to emphasize the fact that, without understating the importance of the 'survival' aspect of an entity, the primary goal of financial statements is to depict the efficiency of asset utilization by the entity. If an asset does not contribute to the generation of the net revenue exceeding the decline in its exit-based valuation, financial statements should enable the extraction of information on this fact, so that the owners could make a decision on the possible termination of the asset, the management or the entity. Exit value provides information on the option available to the entity of the periodic (yearend) opportunistic calculator that may be exploited by selling the assets. However, using this measure may divert the focus of the entity's management solely to the trading function from production and the creation of value.

Against this backdrop, it needs to be understood that the entity's owners would definitely desire to receive information enabling them to decipher the extent to which the entity's management has availed of appropriate asset replacement opportunities. Thus, the alternative valuation methods could be benchmarked against the management's asset replacement decision.

Let us, now, examine the interplay between the exit and entry valuations of an asset. A decision to replace an asset, presently optimally used by the entity, shall be made only if the entry valuation of the services being provided by the asset is less than the exit valuation of the asset providing such services. For assets providing only one service, this situation is unlikely to arise in perfect markets because, in such instances, entities would immediately replace and sell until the values are realigned. Nevertheless, such a scenario is sustainable for the assets providing more than one type of service, e.g. in the following situations, entry values could fall below the corresponding exit values when desired services are provided by a new asset, now available, more cheaply, and when the existing asset's service(s) become more valuable.

The foregoing analysis does unequivocally emphasize the fact that both valuation bases provide significantly valuable and non-overlapping pieces of information for the users of financial statements. It would, thus, be optimally sound 
if the management and other stakeholders could continually be made aware of both valuations of each one of the entity's assets. Financial statements may, thus, be prepared for using the measurements based on both valuation bases. This strategy would further the philosophy behind exit valuation viz. the principle of goal congruence in the construction of evaluation systems. The underlying tenet of such systems is that those actions that are most desired by evaluators viz. the entity's owners are the actions which result in the best evaluation.

We illustrate the impact of the mode of valuation on the example of the income statement and the consequential evaluation of the entity's management, by considering an asset with the following values:

\begin{tabular}{l|cc} 
& \multicolumn{2}{|c}{ Time end of the period } \\
\hline & 2 & 3 \\
Entry value & $1,300,000$ & 600,000 \\
Exit value & $1,050,000$ & 500,000
\end{tabular}

Let the income before depreciation in Period 3 be 650,000 ; then, the net income under exit value works out to $[650,000-(1,050,000-500,000)]=100,000$ while that under entry valuation is $[650,000$ $(1,300,000-600,000)]=-50,000$. Thus, although the exit valuation vindicates the decision made by the entity's management to hold the assets at the beginning of Period 3 and continuing operations during this period, the entry valuation indicates a contrary inference. It follows that the management's performance evaluation based on the entry valuations would provide the inference that the management erred in continuing operations for the said period - it ought to have sold the asset at the beginning of the period. This inference would clearly be contraindicated if the exit valuations had been used for the asset, which would provide testimony to the veracity of the management's decision on continuing operations, at least, for the relevant period. This dichotomy in decision making may be traced to the fact that entry valuation carries the option with the management of not purchasing the asset. However, in the case of an asset already held, this option does not exist in reality, whence entry valuation is, as a matter of principle, not justified for performance evaluation because any evaluation system must be based only on the options available to the evaluatee. This problem in evaluation does not arise if exit valuation is adopted.

Nevertheless, there is an intriguing exception to the above strong advocacy of exit valuation. This arises in the case of the first accounting period, when the asset is considered for purchase. At the commencement of the first accounting period, the management does have the option of not buying the asset at the time of the initial purchase. Thus, in the context of the first accounting period after the asset purchase, income needs to be assessed by comparing the returns from the asset with the reduction in its entry value. If the analysis shows that the latter exceeds the former for the first accounting period, but thereafter the asset returns exceed the decline in the asset's exit valuation, the asset could be acquired (at the entry value) at the end of the first period. Thus, the cost of services in the first period would be the change between the beginning and ending entry values. In summary, then, the following appropriate reporting basis for asset valuations can be stated entry valuations for the first period, and exit valuations thereafter.

The fallout of the above-postulated scheme of valuation that needs addressing is the accounting disposition of possible differences between the entry and exit valuations of an asset at the end of the first period. In this context, the following seems to be logical:

- If exit (entry) valuation is adopted throughout, including the first period, the difference between the entry and exit values should be accounted for at the time of the purchase (disposal) of the asset. This is so because the assets valued on an 
entry (exit) basis will be given up (received) and the purchased (disposed) asset will be valued on an exit (entry) basis.

- However, If any mix of both exit and entry bases is adopted, the difference needs to be recognized and accounted for whenever a change in the method occurs, e.g. if the aforesaid scheme-ofvaluation mix is adopted on an entry basis for the first year and on an exit basis thereafter, the discrepancy has to be accounted for at the end of the first period.

The differences between exit and entry asset valuations, in case a combination of both bases is adopted, may be dealt with either by allocating the difference on the basis of change in exit value or entry value or the equal rate of return, or by ignoring the difference in performance evaluation relating to individual periods.

In summary, the following scheme can be presented:

- Performance evaluation for any period should be done on the valuation basis that reflects the alternatives available to the entity's management in that period;

- The difference, if any, due to the use of a (possible) mix of the valuation bases should be accounted for when the asset's life is evaluated;

- At the point in time the income from the assets shall be determined by comparing the returns generated by the assets with their net cost viz. the excess of the entry value at the time of purchase over the exit value at the time of disposal.

It needs to be emphasized once again, at the cost of being repetitive, that the preceding analysis is premised on the 'asset/liability'-based measure of income, which construes income as the accretion in value between two balance sheets, the philosophy that has regained the favor and confidence of the accounting fraternity in recent years. Nevertheless, if income is determined by the 'matching' concept, entry value tends to camouflage the effects of various external fortuitous events in the expense statement from operating income, whereas exit values tend to highlight such issues (Landsman, 2007; Magnan, 2009; Veron, 2009).

The above debate leads to the unequivocal inference that both bases of valuation have their well-defined and mutually exclusive meritorious features. As such, the financial reporting based on both valuation bases would unquestionably enhance the information content and, therefore, the utility of such statements for stakeholders and users thereof. As an alternative, 'value in use' seems to have the majority of the cardinal attributes required of a value measure. For one thing, value in use encapsulates the value of the asset in the context of the value of the entity. Furthermore, such value in use also harmoniously gels with the 'going concern' convention. Nevertheless, the use of this measure is severely constrained by the problems associated with its reliable ascertainment. Obviously, such determination entails entity-specific inputs, adding to the subjectivity in such calculation. However, logical considerations imply that: value in use shall be more than entry value at purchase, and value in use shall be less than exit value on disposal (Barth \& Landsman, 1995).

\section{INCOME: HICKSIAN INCOME versus FISHERIAN INCOME}

The contemporary financial accounting and reporting framework has Hicksian income as its income measure in contradistinction to Fisherian income (Rayman, 2007). We illustrate these two contrasting methodologies underlying income measurement to facilitate the understanding and 
appreciation of the implications thereof for financial statements by the following example:

A Ltd. is a company having a life span of $n$ years, projected to generate the free cash flows of $C_{i}$ in the year $i$ over this life span. On the basis of an assessment of the risk profile of this company and the prevalent market return rates, the appropriate risk-adjusted discount rate for A Ltd. is determined as $k$ whence its fair value is calculated as:

$$
V=\sum_{i=1}^{n} C_{i}(1+k)^{-1}
$$

Let A Ltd., now, be impacted by an economic event whence its free cash flow projections are modified to $C_{i}{ }^{\prime}$ in the year $i$ together with a change in the risk profile of these cash flows, captured by the revised risk-adjusted discount rate $k^{\prime}$ whence its fair value becomes:

$$
V^{\prime}=\sum_{i=1}^{n} C_{i}^{\prime}\left(1+k^{\prime}\right)^{-1}
$$

Now, if $V^{\prime}$ exceeds $V$, there occurs an accretion in the entity's fair value. This will find its way into financial statements as a gain under the provisions of ASC 820 (FASB, 2001) or the corresponding IFRS 13 (IASB, 2012). This is in line with the Hicksian concept of income. However, the recognition of this gain may strongly violate the convention of 'conservatism', for the income so recognized may not actually have been realized at that point in time. In fact, the income may be construed to have actually been realized if, and only if, the investors of A Ltd. liquidate their investments in the entity forthwith to realize the market value of their holdings and then spend it immediately. In the event that such investors reinvest the proceeds of the sale of their holdings or equivalently, defer consumption for $m<n$ years, the market realizations of their holdings at the end of $m$ years would now be $V^{\prime}\left(1+k^{\prime}\right)^{m}$, rather than $V(1+k)^{m}$, due to the impact of the economic event. If $V^{\prime}>V$ and $k^{\prime}<k$, then $V^{\prime}\left(1+k^{\prime}\right)^{m}$ need not necessarily exceed $V(1+k)^{m}$.
There is the cutoff point:

$$
m=\frac{\log V-\log V^{\prime}}{\log (1+k)-\log \left(1+k^{\prime}\right)}
$$

at which $V^{\prime}\left(1+k^{\prime}\right)^{m}=V(1+k)^{m}$. For consumption periods shorter than this cutoff, the investor would benefit more by deferring consumption, and vice versa.

The recognition of any unrealized increase in fair value is fundamentally erroneous. This is so because any accretion in fair value that is not realized forthwith may not necessarily be translated into increased consumption power if realized at a later date. Thus, the reporting on accretion in fair value as a gain in the income statement is 'true and fair' only if all investors intend to instantly consume such accretion - a scenario grossly unrepresentative of the ground realities. In fact, this is where the merit of the Fisherian concept of income sets in.

This Hicksian concept of income (Hicks, 1946; Solomons, 1961) is not necessarily compatible with the asset/liability perspective now being advocated by the FASB and IASB. There are several reasons for this. To start with, the FASB and IASB have claimed objectivity in measurement as cardinal for shifting to the 'asset/liability' approach to income measurement. However, this claim seems implausible. There is unequivocal evidence that an entity's assets, other than its identifiable net assets, contribute significantly to its earning capacity. These assets, including human capital, may not be tradeable; hence, the estimation of their market values may be beset with imprecision. Thus, the incompleteness of markets, even if they are in competitive equilibrium, may generate internal goodwill, whose measurement is largely subjective, to say the least (Van Cauwenberge \& DeBeelde, 2007).

Another impediment to the adoption of the Hicksian concept of income also relates to its measurement. Hicksian income is measured not by a change 
in the value of the net assets of the entity, but by a change in the value of the entity itself instead. Precisely speaking, the latter represents the income of the owners of the entity, rather than that of the entity's business. Such change in the entity's value, even ex post, is primarily caused by the changed expectations of the entity's future cash flows. The change is not substantively brought about by the realized cash flows of the relevant period (Benston et al, 2006; Bromwich, 2007; Hitz, 2007; Dean, 2008; Sunder, 2008).

The adoption of the Hicksian concept of income for financial reporting also seems fallible on the grounds of making reporting fundamentally inefficacious. J. Hicks himself accepted that any practical ex post measure of income is largely irrelevant for decision making. It is conceded that reporting on such a basis can, at best, have predictive value only to the extent of providing relevant statistics. However, this may imply that decision makers, as users of such statements, may be the best persons to make, on their own, necessary adjustments in the data of past transactions so as to provide for changes in future expectations. However, if this is to be so, the option in the hands of such users of using decision support systems from within or outwith the entity, such as outputs provided by analysts, the press and academicia for ancillary and supporting inputs in lieu of adjusting financial statements may turn out to be superior on the premise that the unsubstantiated and estimated inputs of the future would not find their way into audited financial statements and reports.

The issue relating to the suitability of or otherwise to Hicksian income in the financial reporting system subsists in perfect markets as well. This is unlike several other characteristics of FVA that emanate from market imperfections.

\section{CONCLUSION}

In this paper, an attempt has made to examine several issues occupying center stage in the contemporary accounting environment viz. transition to the 'asset/liability' conceptual framework for income determination, the use of exit-based valuation in measuring the 'fair value' of assets and liabilities, and the adoption of the Hicksian measure of income. Various implications of these aspects have been assessed and reported. The antagonists of the current accounting paradigm are likely to strongly espouse their concerns on these lines. The incumbent analysis highlights the cardinal issues that warrant serious discussion and debate among the accounting fraternity. It is universally accepted that accounting information needs to be significantly relevant for use in the user's decision making processes. The contentions raised herein tend to dilute this relevance of financial reporting for end users.

The analysis of the pronouncements of the regulatory bodies together with the review of the relevant literature presented in this work unequivocally reject the null hypotheses set up, leading to the acceptance of the 'alternative' hypotheses viz.

H1: The 'asset/liability' conceptual framework recommended by the FASB and IASB does not invariably correctly report the financial affairs of an entity.

H2: The exit-based valuation adopted by the FASB and IASB in the definition of the 'fair value' of assets and liabilities is not the appropriate accounting measure of 'fair value' in all circumstances.

H3: The 'Hicksian' concept of income adopted by the FASB and IASB, in conjunction with the 'asset/liability' framework, is not essentially the appropriate accounting measure of income.

It must, however, be emphatically underscored that this is purely a theoretical study. Although the findings seem to be unequivocal, the study carries the author's perceptions, views, skill and understanding and interpretations as its main limitation. There is, therefore, a possibility that 
the inferences of the study could be influenced by such perceptions, biases and interpretations. This observation opens up vistas for future research. Empirical studies may be undertaken to corroborate and validate these findings. Ideally, conceptual inferences should invariably be validated by empirical studies for trustworthy inference. However, the inferences obtained through statistical analysis may also need to be accepted with caution, howsoever sophisticated these tools may be. Besides, the studies that explore the various issues relating to human decision making have certain intrinsic limitations. There is no mathematical framework that can model such decision making processes quantitatively in all their degrees of freedom. Any quantitative model invariably involves the truncation of the system space by a reduction in the number of the degrees of freedom that can be tracked. This causes fuzziness in system modeling with a loss of information. Consequently, it becomes impossible to frame the set of the evolution equations that could possibly lead to an exact mathematical solution to such problems.

In addition to the possibility of taking up empirical studies in order to validate the findings herein, research programs need to be taken up by professional accounting bodies and practitioners' forums so as to identify, develop and formulate a conceptually superior accounting framework that cuts through the ambiguities created by the issues presented herein. Medium-term research that explores further shortcomings/limitations of the contemporary framework in its current applications or identifies further sectors/areas which could be targeted in order to improve the quality of financial reporting could also be contemplated.

However, it does seem that the conceptual framework presently propounded by the FASB and IASB may not be able to dispense with either of the two issues highlighted in this article viz. the use of exit valuation together with the Hicksian concept of income forthwith, although the shift of emphasis to the 'asset/liability'-based conceptual framework is clearly discernible except, possibly, in a few cases where the revenue/expense model is retained for the reason of its being more representative of the maintainable earnings concept. There is some indication of a review of this movement by the FASB and IASB in their Revenue Recognition and Fair Value Projects. It is important to emphasize at this point that the issues raised herein can also be sourced to the well-entrenched conventions that form the backbone of business performance appraisal. Although these conventions may lack scientific and/or rational underpinnings, yet their existence and role in accounting practice cannot be disputed. Thus, for a cohesive accounting framework/model, the interrelationships between concepts and conventions need to be embedded therein. Merely the adoption of Hicksian income as a measure neither implies nor is implied by an exclusive asset/liability-based income determination, nor does it facilitate the use of ex post financial reporting for assessing business performance. The 'objectivity' and 'unambiguity' of Hicksian income for financial reporting, so claimed by the FASB and IASB, seems to be substantively overstated. However, notwithstanding the flaws embedded in the conceptual underpinnings of FVA, as espoused hereinbefore, its gradual, but rapid, acceptability and adoption among standard setters is unequivocally welcome - it represents a paradigm shift in emphasis among the accounting fraternity towards the 'relevance' of financial reporting to the users thereof. An encouraging start to ushering in the era of 'fair value accounting' has been made. Understandably, some critical aspects need addressing, but these represent evolutionary glitches, rather than catastrophic mis-endeavors. FVA is widely being viewed as an integral constituent of the regulator's toolbox for ushering in an efficacious suite of upgradations for userfriendly financial reporting. There seems to be little doubt that the philosophy of fair value accounting is here to stay and should be fostered by all its votaries. 


\section{REFERENCES}

American Accounting Association's Financial Accounting Standards Committee. (2007). The FASB's conceptual framework for financial reporting: A critical analysis. Accounting Horizons, 21(2), 229-238. doi.org/10.2308/ acch.2007.21.2.229

American Accounting Association's Financial Accounting Standards Committee. Ohlson, J. A., Penman, S., Bloomfield, R., Christensen, T. E., Colson, R., Jamal, K., Moehrle, St., Previts, G., Stober, T., Sunder, S., \& Watts, R. L. (2010). A framework for financial reporting standards: Issues and a suggested model. Accounting Horizons, 24(3), 471-485. doi.org/10.2308/acch.2010.24.3.471

Barth, M. E. (2007). Standard setting measurement issues and the relevance of research. Accounting and Business Research, Special Issue, 7(1), doi.org/10.1080/00014788.20 07.9730079

Barth, M. E., \& Landsman, W. R. (1995). Fundamental issues relating to using fair value accounting for financial reporting. Accounting Horizons, 9(4), 97-107.

Benston, G. J. (2006). Fair-value accounting: A cautionary tale from Enron. Journal of Accounting and Public Policy, 25(4), 465-484. doi.org/10.1016/j.jaccpubpol.2006.05.003

Benston, G. J. (2008). The shortcomings of fair value accounting described in SFAS 157. Journal of Accounting and Public Policy, 27(2), 101-114. doi.org/10.1016/j. jaccpubpol.2008.01.001

Benston, G. J., Bromwich, M., \& Wagenhofer, A. (2006). Principles- versus rules based accounting standards: The FASB's standard setting strategy. ABACUS, 42(2), 165-188. doi: 10.1111/j.1467-6281.2006.00196.x

Boulton, R. E. S., Libert, B. D., \& Samek, S. M. (2000). Cracking the Value Code: How Successful Businesses are Creating Wealth in the New Economy. New York, NY: HarperBusiness.

Bromwich, M. (1992). Financial Reporting, Information and Capital Markets. London, UK: Pitman.

Bromwich, M. (2001). The ACCA/BAA distinguished academic 1999 lecture- angels and trolls: The ASB's statement of principles for financial reporting. The British Accounting Review, 33(1), 47-72. doi.org/10.1006/ bare. 2000.0150
Bromwich, M. (2007). Fair values: imaginary prices and mystical markets. In P. J. Walton (Ed.). The Routledge Companion to Fair Value and Financial Reporting. London, UK: Routledge.

Chabrow, E., \& Colkin, E. (2002). Information Week.

Christensen, J. A. (2010). How do conceptual frameworks contribute to the quality of corporate reporting regulation? Accounting and Business Research Special Issue: International Accounting Policy Forum.

Christensen, J. A., \& Demski, J. S. (2003). Accounting Theory. An Information Content Perspective. New York, NY: McGraw-Hill.

Dean, G. W., \& Clarke, F. L. (2003). An Evolving Conceptual Framework. ABACUS, 39(3), 279-297. doi: 10.1111/j.14676281.2003.00133.x

Dean, G. W. (2008). Editorial: Conceptual Frameworks, Fair Value Measurement and Decision Making. ABACUS, 44(3), I-VII. doi: 10.1111/j.1467-6281.2008.00260.x

Dennis, I. (2006). Here We Go Again ..., Oxford Brookes University Working Paper, available as Comment Letter \#50 on the IASB/FASB project website: http://www. iasb.org/NR/rdonlyres/2D4D6717-557F-47AA-8BB2A22E6FCCADF0/0/CL50.pdf

Dennis, I. (2008). A conceptual enquiry into the concept of a "principles-based" accounting standard. The British Accounting Review, 40(3), 260-271. doi.org/10.1016/j. bar.2008.05.005

Eccles, R. G., Herz, R. H., Keegan, E. M., \& Philips, D. M. H. (2001). The Value Reporting Revolution: Moving Beyond the Earnings Game. New York, NY: John Wiley.

Eckstein, C. (2004). The measurement and recognition of intangible assets: Then and now. Accounting Forum, 28(2), 139-158. doi.org/10.1016/j.accfor.2004.02.001

Financial Accounting Standards Board. (2000). Financial Accounting Standard 133. Accounting for Derivatives and Hedging Activities, USA.

Financial Accounting Standards Board. (2001). Financial Accounting Standard 141. Business Combinations, USA.

Financial Accounting Standards Board. (2001). Financial Accounting Standard 142. Goodwill and Other Intangible Assets, USA. 
Financial Accounting Standards Board. (2001). Financial Accounting Standard 157. Fair Value Measurements. USA.

Financial Accounting Standards Board. (2009). Accounting Standards Code 820. Fair Value Measurements. USA.

Gwilliam, D., \& Jackson, R. H. G. (2008). Fair value in financial reporting: problems and pitfalls in practice. Accounting Forum, 32(3), 240-259. doi.org/10.1016/j. accfor.2008.01.003

Hicks, J. R. (1946). Value and Capital. Oxford, Clarendon Press.

Hitz, J. M. (2007). The decision usefulness of fair value accounting - A theoretical perspective. European Accounting Review, 16(2), 323-362. doi. org/10.1080/09638180701390974

International Accounting Standards Board. (2012). International Financial Reporting Standard 13, Fair Value Measurements.

Landsman, W. R. (2007). Is fair value accounting information relevant and reliable? Evidence from capital markets. Accounting and Business Research, 37(1), 19-30. doi.org/10.1080/00014788.2007.9730081

Lev, B. (2001). Intangibles: Management, Measurement and Reporting. Brookings Institution Press.

Magnan, M. (2009). Fair value accounting and the financial crisis: Messenger og contributor? Accounting Perspectives, 8(3), 189-213. doi: 10.1506/ap.8.3.1

Nissin, D., \& Penman, S. (2008). Principles for the application of fair value accounting. White Paper No. 2, Columbia Business School.

Penno, M. C. (2008). Rules and accounting: Vagueness in conceptual frameworks. Accounting Horizons, 22(3), 339351. doi.org/10.2308/acch.2008.22.3.339

Potter, B. (2005). Accounting as a social and institutional practice: Perspectives to enrich our understanding of accounting change. ABACUS, 41(3), 265-289. doi: 10.1111/j.1467-6281.2005.00182.x

Rayman, R. A. (2006). Accounting Standards: True or False? Routledge.
Raymen, R. A. (2007). Fair value accounting and the present value fallacy: the need for an alternative conceptual framework. The British Accounting Review, 39(3), 211-225. doi.org/10.1016/j.bar.2007.03.006

Solomons, D. (1961). Economic and accounting concepts of income. The Accounting Review, 36(3), 374-383.

Sundem, G. L. (2007). A Note on the Information Perspective and the Conceptual Framework. In R. Antle, F. Gjesdal, \& P. J. Liang (Eds.), Essays in Accounting Theory in Honour of Joel S. Demski (pp. 285-293). New York, NY: Springer.

Sunder, S. (1997). Theory of Accounting and Control. Cincinnati, OH: South-Western.

Sunder, S. (2008). Econometrics of Fair Values. Accounting Horizons, 22(1), 111-125. doi: doi.org/10.2308/ acch.2008.22.1.111

Uzma, S. H., \& Singh, J. P. (2009a). Intangibles accounting Issues \& dimensions. The Accounting World, 19.

Uzma, S. H., \& Singh, J. P. (2009b). Brand Recognition: The Contemporary Scenario. Chartered Secretary.

Veron, N. (2009). Fair value accounting is the wrong scapegoat for the crisis. European Accounting Review, 5(2), 63-69. doi.org/10.1080/17449480802510542

Van Cauwenberge, P., \& DeBeelde, I. (2007). On the IASB comprehensive income project: an analysis of the case for dual income display. ABACUS, 43(1), 1-26. doi: 10.1111/j.1467-6281.2007.00215.x

Watts, R. (2003a). Conservatism in accounting Part I: Explanations and implications. Accounting Horizons, 17(3), 207-221. doi.org/10.2308/acch.2003.17.3.207

Watts, R. (2003b). Conservatism in accounting Part II: Evidence and research opportunities. Accounting Horizons, 17(4), 287-301. doi.org/10.2308/acch.2003.17.4.287

Wells, M. (2003). Forum: The Accounting Conceptual Framework. Introduction. ABACUS, 39(3), 273-278. doi: 10.1111/j.1467-6281.2003.00132.x

Whittington, G. (2008). Fair Value and the IASB/FASB Conceptual Framework Project: An Alternative View. ABACUS, 44(2), 139-168. doi: 10.1111/j.14676281.2008.00255.x 


\section{Received on $20^{\text {th }}$ December 2016, after one revision, accepted for publication on $24^{\text {th }}$ April 2017. \\ Published online on $28^{\text {th }}$ April 2017.}

Jatinder Pal Singh, PhD, is a Professor at the Indian Institute of Technology Roorkee and a professional member of the Institute of Chartered Accountants of India, Institute of Cost Accountants of India, Institute of Company Secretaries of India and Institution of Engineers (India). His research interests are in econophysics, mathematical finance, financial risk management, international finance and corporate governance. 


\title{
ON THE CONCEPTUAL UNDERPINNINGS OF FAIR VALUE ACCOUNTING
}

\author{
Jatinder P. Singh* \\ Department of Management Studies, Indian Institute of Technology Roorkee, Uttarakhand, India
}

The metamorphosis of business processes and corporate strategies is rapidly progressing across the globe. The critical role of intangibles in corporate performance is receiving its due recognition. Complex tradeable financial products are flooding financial markets. In attempts to gear up for the challenge of financial reporting in this upstaged environment, standard setters have substantively restructured reporting systems, with 'fair value' being the bedrock thereof. Moving away from the traditional 'revenue/ expense' matching measure of income towards the 'asset/liability' measure together with the adoption of the Hicksian concept of income is clearly discernible in the pronouncements and ongoing projects of the US Financial Accounting Standards Board (hereinafter referred to as FASB) and the International Accounting Standards Board (hereinafter referred to as IASB ). In this article, an attempt is made to analyze the issues that are controversial and equivocal, or those that need further refinement insofar as fair value accounting is concerned.

Keywords: fair value, financial accounting, 'exit' and 'entry' values, income, conceptual framework, FASB, IASB, asset/liability measure

\section{JEL Classification: G30, M41, N30}

\section{INTRODUCTION}

Financial statements prepared under statutes and/or regulatory pronouncements are invariably mandated to portray a 'true and fair' picture of the reporting entity's financial affairs. Thus, it may either be that such financial statements have, hitherto, presented a 'true and fair' description of the entity's financial position and performance (whence no radical

* Correspondence to: J. P. Singh, Department of Management Studies, Indian Institute of Technology Roorkee, 247667 Uttarakhand, India; e-mail: jpsiitr@gmail.com changes in the regulatory framework were required) or that, paradoxically, provisions or applicable pronouncements have continually been violated. Nevertheless, the paradox is easily resolved. Society is continuously evolving and so is human knowledge and understanding. With this progression, the perceptions and, indeed, the defining characteristics of 'true and fair' are undergoing radical changes. Thus, what has been perceived to be 'true and fair' hitherto may not be understood in the same sense hereon. The two defining features of financial reporting are reliability and relevance, with an inter 
se tradeoff between them dictating the underlying philosophy of all financial reporting models. Hitherto, reliability has been perceived as critically important in financial reporting, leaving relevance relatively unattended. The accounting fraternity worldwide has been obsessed with the ascendancy of 'reliability' over 'relevance'. However, times have moved on and views have changed almost diametrically in the preceding few decades. With the increase in the contribution of intangibles and complex financial products in contemporary business (Boulton, Libert \& Samek, 2000; Eccles, Herz, Keegan \& Philips, 2001; Lev, 2001; Chabrow \& Colkin, 2002), the tradeoff has perceptibly tilted in favor of the 'relevance' of financial reporting to stakeholders and other users (Eckstein, 2004; Uzma \& Singh, 2009a; 2009b). As party to this transition, 'income' characterization has moved back from the 'matching' approach to the 'asset/liability' approach, signaling a radical shift in the underlying 'conceptual basis of financial reporting'. Furthermore, the appropriateness of associating 'income' with the marketplace by using market-based valuations is felt immensely desirable by the community, thereby ushering in the era of fair value accounting (FVA).

Financial reporting under the 'fair value' based accounting system states assets and liabilities at their respective current values. Therefore, this accounting system is occasionally called 'mark-tomarket' accounting. Formally, 'fair value' is defined in Accounting Standards Code 820 (FASB, 2009) (formerly SFAS 157; FASB, 2001) of the US and the corresponding IFRS 13 (IASB, 2012), in essence, as 'the price that would be received to sell an asset or paid to transfer a liability in an orderly transaction between market participants at the measurement date.' Nevertheless, the very definition of 'fair value' is beset with controversies and ambiguities. For one thing, accounting standards define the 'fair value' of assets and liabilities conceptually in terms of respective 'exit value', rather than their 'entry value'. This aspect assumes immense significance in environments beset with market frictions and other imperfections. Another critical source of ambiguity and controversy in the contemporary accounting setup that was identified in course of the literature review was the adoption of Hicksian income as its underlying philosophy. However, an equally popular conceptual approach to income measurement is attributed to the noted economist I. Fisher (referred to as Fisherian income) (Rayman, 2007).

This article has the key objective to examine the implications of these issues that have left fair value accounting short of being a perfect accounting framework, rather than a 'panacea for all evils'. Precisely, we explore the ramifications of:

- the paradigm shift of the accounting regulatory bodies to the redefinition of the conceptual basis of reporting from the 'revenue/expense' approach to the 'asset/liability' model;

- the use of 'exit' value in contradistinction to the 'entry' value and the 'value in use' in defining 'fair value';

- the adoption of 'Hicksian' income as the underlying philosophy of income measurement.

This paper's objectives have been attained through a comprehensive and critical study of the conceptual underpinnings of the pronouncements of the accounting regulatory bodies and a detailed review of the relevant research literature.

In line with the study's objectives, the following null hypotheses are set up for evaluation:

H1: The 'asset/liability' conceptual framework recommended by the FASB and IASB invariably correctly reports the financial affairs of an entity;

H2: The 'exit'-based valuation adopted by the FASB and IASB in the definition of the 'fair value' of assets and liabilities is the appropriate accounting measure of fair value in all circumstances;

H3: The 'Hicksian' concept of 'income', adopted by the FASB and IASB, in conjunction with the 'asset/liability' framework, is essentially the appropriate accounting measure of income;

with the usual corresponding respective alternative hypotheses. 
We put these hypotheses to test through a study aimed at analyzing various standards and other pronouncements of the FASB and IASB and their possible impact on the adoption of the 'asset/liability' framework, the 'exit'-based definition of fair value and the Hicksian concept of income by affected entities.

It is pertinent to point out here that SFAS 157 (FASB, 2001) and several other related standards have been substantively adapted into the Accounting Standard Code (ASC) promulgated by the United States Financial Accounting Standards Board (FASB). This ASC of the FASB constitutes the complete source of the extant authoritative Generally Accepted Accounting Principles (GAAP), recognized by the FASB, to be applied to nongovernmental entities. The ASC is effective for interim and annual periods ending after September 15, 2009. It has been formulated through the comprehensive restructuring and reorganizing of the various pronouncements of the FASB from time to time and now constitutes the sole authoritative diktat of the FASB on the US GAAP, superseding all the erstwhile accounting standards. All accounting literature not explicitly included in the ASC has been declared to be non-authoritative by the FASB.

\section{CONCEPTUAL FRAMEWORKS FOR FINANCIAL REPORTING}

There are two alternative conventional conceptual frameworks underlying the preparation of the financial statements of an entity viz. the 'revenue/ expense' approach and the 'asset/liability' approach (Nissin \& Penman, 2008). Under the former approach, the income statement, which is formulated as a matching of the revenues and expenses relating to the relevant accounting period, is the primary accounting output. It portrays the performance and progress attained by the entity in executing an envisaged business model, whereas the balance sheet is returned as a residual. As such, the value figures in the balance sheet do not and are not intended to reflect the present values of projected future cash flows or other business valuations in any sense. The eventuality of their reflecting such valuations is an idealization bordering on aberration. The accounting standards of and conventions on 'Revenue Recognition' dictate the modus operandi for recognizing and gains. Compliance with the 'matching' principle ensures that expenses and revenues are properly matched and related to the same accounting period.

The balance sheet under the 'revenue/expense' approach constitutes the grouping of residuals. Such residuals arise from timing differences, so that assets are the accounts that are likely to enter into future income statements as and when their consumption actually takes place for producing income/cash flows (in accordance with the 'matching' principle). Liabilities are similarly construed. Most balance sheet accounts, other than those arising on account of revenue recognition, are not market marked. As such, they do not indicate economic values, nor do they represent the present valuations of future cash flows. They are merely the expressions of consumption value as per the business model being pursued by the entity.

In the 'asset/liability' approach, assets and liabilities are the primary elements and are defined initially. They form the basis for defining the other accounting elements viz. 'equity', 'income' and 'expenses'. Income for an accounting period equals the change in net assets (apart from transactions with owners). Thus, the emphasis shifts from the income statement (which, now, becomes a collection of residuals) to the balance sheet. The income statement merely presents the changes in valuations between the beginning and the end of the relevant accounting period.

Against the above, the primary merit of the 'revenue/ expense' approach propounded by its votaries is that it enables the smoothening out of the volatile effects of certain types of transactions through the mechanism of deferring charges and credits. The 'asset/liability' approach may result in a fluctuating income statement that may include unrealized holding gains and losses (Benston, 2006; Gwilliam \& Jackson, 2008).

Presently, there is an unambiguous perception of the superiority of the 'asset/liability' approach, primarily on account of its following attributes: 
- Assets and liabilities are real, usually physical and tangible objects. As such, they are more amenable to actual identification, classification and measurement than the contents of the income statement. The adoption of the 'asset/liability' approach thus adds to precision in financial reporting.

- The 'causal' flow also advocates the 'asset/liability' approach. i.e. a change in the value of net assets constitutes the 'cause' and income is the 'effect' thereof, not the other way round.

Of late, the 'asset/liability' approach has found immense favor with the standard setters, in particular with the IASB, as testified by the IASB's Conceptual Framework of 2010 that defines an asset as a 'resource controlled by the entity as a result of past events and from which future economic benefits are expected to flow to the entity' and a liability in the same vein as 'a present obligation of the entity arising from past events, the settlement of which is expected to result in an outflow from the entity of resources embodying economic benefits'. Thereafter, the said framework goes on to define income in terms of the op-defined assets and liabilities as increases in economic benefits during the accounting period in the form of inflows or enhancements of assets or decreases of liabilities that result in increases in equity, other than those relating to contributions from equity participants'. Although this transition to the 'asset/liability' approach is wellreceived by stakeholders in general, several aspects of the framework need ironing out (Bromwich, 1992; Sunder, 1997; Christiansen \& Demski, 2003; Watts, 2003a; 2003b; Benston, Bromwich \& Wagenhofer, 2006; Sundem, 2007; Benston, 2008; Whittington, 2008; Christiansen, 2010). Appreciating this concern, the IASB has invited comments through the issue of Discussion Paper No. DP/2013/1 in July 2013.

Some proponents of the 'asset/liability' approach perceive the existence of a strong nexus between this approach and the recognition, measurement and carrying of accounts at fair values to the extent that the former implies the latter. This presumption, however, seems questionable, as evidenced by the following counterexamples:
- Consider the situation when a customer makes an advance payment prior to the actual delivery of goods. Most of us would agree that revenue recognition should take place in the accounting period in which the job to which the payment pertains is actually performed. This would be the period in which the payment is earned. Prior thereto, it should be recorded as deferred revenue. In case the job is spread over several accounting periods, we note that the asset that is driving revenue recognition is the job being performed for the customer. As such, revenue should be recognized commensurate with the value enhancement (determined by some appropriate estimation process) of the job. This is analogous to the percentage completion method.

- An alternative to above would be to recognize revenue on the basis of the entity's satisfaction of its own contractual commitment to transfer the good to the customer. In this model, revenue recognition is driven by the entity's contractual commitment to transfer the good to the customer. This model would yield outcomes similar to the usual 'delivery' models.

- The third choice would be to recognize revenue as and when actual cash is received from the customer. In this case, the cash itself is the asset that drives the revenue recognition process. This, in fact, constitutes the cash basis of accounting.

The above accounting conundrum, along with several others, was deliberated as part of the Joint FASB and IASB Project on Revenue Recognition, completed in June 2014. Intense discussions eventually culminated in the Boards' agreeing to adopt, as the general rule, that revenue shall be recognized by an entity upon its compliance with its contractual obligation to transfer a good or service to the customer. More importantly, however, having established this standard of recognizing revenue commensurate with changes in the value of a liability (i.e. the entity's performance obligation under the contract with the customer), the Boards did not jump forthwith to measuring this liability on the basis of fair value. On the contrary, it was ultimately resolved that the said performance 
obligation of the entity should be measured by the allocation of the measure of the rights in the contract to all of the identified performance obligations. Thus, in this particular instance, although the 'asset/ liability' approach was applied to revenue recognition insofar as revenue recognition was linked to changes in the value of a liability, the measurement of that liability was not prescribed at fair value.

Notwithstanding the above anomaly, not as an imperative consequence of adopting the 'asset/ liability' approach, but rather as a judicious conscious decision stemming from a desire to make reporting more aligned with economic substance, rather than statistical accuracy, the IASB seems to have made a paradigm shift in order to usher in FVA as rapidly as practicable. It would be in place, therefore, to discuss the conceptual underpinnings of FVA, fair value and the income measurement strategy under FVA (Bromwich, 2001; Dean \& Clarke, 2003; Wells, 2003; Potter, 2005; Dennis, 2006; 2008; Rayman, 2006; AAA, 2007; 2010; Penno, 2008).

\section{THE CONCEPTUAL BASIS OF FAIR VALUE ACCOUNTING}

The cardinal activity in the overall process of financial reporting is, obviously, the value 'measurement' process (Barth, 2007). Two elemental constituents (sub-processes) aggregate to form this measurement activity viz. choosing a suitable measurement base, e.g. the historical cost, fair value at entry (the replacement cost), fair value at exit (net realizable value), value in use etc., and measuring the relevant account in the selected measurement base.

A structured procedure is put in place by the provisions of the US ASC 820 (FASB 2009), which may be regarded as the benchmark in FVA for addressing the latter issue. However, the choice of the measurement base is left open to the discretion of the entity adopting FVA. In other words, ASC 820 (FASB, 2009) gives us the methodology for calculating fair value, on the one hand, but fails to explicitly set out the circumstances in which FVA is to be adopted, on the other. As exceptions to this norm, FVA is prescribed exclusively or as an alternative in the context of some categories of assets in the provisions of several other FASB standards, e.g. SFAS 133 (Accounting for Derivatives \& Hedging Activities; FASB, 2000), SFAS 141 (Business Combinations; FASB, 2001), SFAS 142 (Accounting for Intangibles; FASB, 2001) and so forth.

The votaries of FVA cite the following in support of its efficacy:

- Financial statements are primarily used in order to make economic decisions;

- An entity's current and prospective investors and creditors are the reference users of its generalpurpose financial reporting. The primary purpose for which these interest groups would use the entity's financial statements is to assess its investment and credit worthiness. For this objective to achieve, they would make suitable future cash flow forecasts. Thus, it would be desirable from this perspective that accounting information, as reported in financial statements, should be aligned with the future to the extent possible, rather than reflect the past. Reporting the information that reflects the past would only serve this purpose if it were indicative of the future and, therefore, useful for making projections. Now, fair valuations encapsulate presentation in terms of the present values of future cash flows.

- The cardinal attribute of financial statements is, now, strongly perceived to be 'relevance', in contradistinction to 'reliability'. Reliability has largely been overshadowed by the attribute of representational faithfulness in the context of financial reporting.

- Prices are believed to give an unbiased assessment of the present values of cash flow forecasts in efficient market conditions. Thus, these figures are based on the economic behavior of the aggregates of market players instead of entity-specific assessments. One may also assume representational faithfulness to be present in contemporary markets on account of high efficiency and completeness. 


\section{'FAIR VALUE': 'EXIT' versus ‘ENTRY' VALUE}

Fundamentally, this issue relates to the relative superiority of the valuation of assets and liabilities for financial reporting at the funds they would generate on sale (current exit value) vis-à-vis the funds necessary for making them available to and ready for the entity to use (current entry value). In a marketplace endowed with pure and perfect competition, with no market frictions, these two measures of value would converge. However, in the presence of significant market frictions, like transaction costs, commissions, transportation costs, etc., the net cash inflows received by the seller are likely to be different from the cash payments made by the buyer. As such, in most real-life situations, the exit value of an asset may be significantly different (usually lower) than its entry value. Before proceeding to an analysis of this issue, we set forth the relative features and virtues of both.

The exit value of an asset is the maximum net amount that can be obtained on the sale/disposal of that asset in the normal course of business (i.e. not in a forced sale) in a short period of time. For this purpose, the net amount represents the sale proceeds less the costs of disposition, on a post-tax basis, discounted to the date of financial reporting/valuation, as desired.

Precisely, the exit value of an asset determines, in monetary terms, the generalized command over the resources that the accounting entity can attain by selling the relevant asset. The entry value, on the other hand, ascertains the present cost of acquiring the cheapest asset (in the markets in which the entity normally trades) that provides to the entity, services congruent to those that the asset being valued is providing en presenti and is expected to provide in future.

It would seem that exit value would, prime facie, be the more relevant form of asset valuation in the context of bodies corporate on the following premises:

- The primary objective of bodies corporate is to further the interests of their stockholders;
- Exit valuation would provide information on the amount that can be realized by the entity and distributed to the stockholders through the sale of the relevant asset in the normal course of business;

- The amount so realized and distributed to the stockholders could be used by them to satisfy some of a variety of wants (that they may have) through the expenditure of the distributed proceeds.

Another characteristic that strongly favors exit valuation relates to the computation of return ratios from financial statements. The principle adopted for asset valuation impacts both the denominator (directly as the value of the funds employed) and the numerator (in the form of a depreciation charge) of these ratios. Now, at any point in time, the realistically viable options available to an entity's management are either to 'sell' or 'not sell' the assets it possesses (that are the subject matter of the valuation). Thus, it would seem that the appropriate valuation of such assets would be at the amount for which they could be exchanged (i.e. exit value), rather than the current market price of equivalent assets. Exit value represents the implicit current investment in an asset. Return computed on entry valuation is based on the investment that the entity's management refuses to renounce in exchange for receiving the assets. Entry valuation seems redundant on this count because the action of 'not buying' the asset may not be acceptable whence the return calculated on the basis of entry valuation would tantamount to a performance measure that the entity's management has discretion to refuse. The evaluation of the entity's management through benchmarking against such a measure would amount to evaluating them on the premise of an investment that they might now refuse. However, return computed on exit valuation is based on the investment that the entity's management refuses to accept in exchange for the assets, the base that is relatively fair and equitable.

Let us now look at the numerator of return computation. For facilitating consistency, this should reflect the income generated from the deployment of the assets constituting the denominator. 
Contemporary theorists prefer to define income (loss) as the surplus (deficit) of the aggregate of the net revenue (before depreciation, but after charging all 'matching' expenses) generated during the relevant accounting period together with the saleable value of the net fixed assets at the end of the said accounting period less the saleable value of the net fixed assets at the beginning of the said accounting period. Equivalently, income (loss) would be the surplus (deficit) of net revenues over the decline in the net saleable (exit) value of the fixed assets over the period. It follows as a corollary that the existence of income is prima facie the testimony of the veracity of the management's decision taken at the beginning of the accounting period in order to continue operations for the accounting period by holding on to the assets because the net cash revenues generated from the use of these assets exceeded the decline in their exit value (depreciation). On the other hand, if an entry-based asset valuation is adopted, depreciation reflects the change in the 'cost of acquisition' of the said assets over the relevant accounting period. The corresponding return ratio is, therefore, built on the premise that the entity's management had the option of retaining the market price of the asset in lieu thereof at the beginning of the accounting period, which, in fact, they never did have. It follows that net income as well as depreciation in the return ratios need to be computed on the basis of exit values so as to enable a meaningful interpretation of such ratios.

On the other hand, the entry value of an asset emphasizes the 'going concern' characteristic of an entity. It assumes the survival of an entity as a 'necessity', for the attainment of which it may need to replace an asset that goes out of commissioning. This obligatory replacement would, obviously, involve the acquiring of the equivalent asset at the current market price, i.e. entry value. Thus, in the event that a positive income is returned based on this valuation philosophy, the survival of the entity as a going concern may justifiably be inferred, and vice versa. 'Survival' in this context is also characterized by the entity's ability to replace the used services so that the expense should also be measured by the current acquisition cost (entry cost) of those services. In this scenario, income is not precisely the surplus of the end of the accounting period balance sheet over the one at the beginning of the accounting period. A significant merit of entry valuation is that it facilitates comparability among entities, thereby enhancing the utility of the statements so prepared. The statements would also be indicative of the nature and context of the resources that the entity expects to use in its projected activities. As mentioned earlier, the cardinal application of financial statements is to help make future projections by investors and creditors. In this context, entry valuation would seem to hold an edge over exit valuation, the choice, basically representing the tradeoff between information on the entity's intention (entry) and the entity's flexibility (exit) for the future. The exit valuation of assets that purports to indicate the cash market value of the relevant assets is largely of current interest only, being reflective of the entity's flexibility. Furthermore, such exit valuation is likely to be relatively much less precise as it represents the valuation of the assets in their second or third best use. Anomalous situations may also arise in instances where the expenses of asset disposal exceed the market value of the asset, resulting in negative exit valuations.

At this point, it is necessary to emphasize the fact that, without understating the importance of the 'survival' aspect of an entity, the primary goal of financial statements is to depict the efficiency of asset utilization by the entity. If an asset does not contribute to the generation of the net revenue exceeding the decline in its exit-based valuation, financial statements should enable the extraction of information on this fact, so that the owners could make a decision on the possible termination of the asset, the management or the entity. Exit value provides information on the option available to the entity of the periodic (yearend) opportunistic calculator that may be exploited by selling the assets. However, using this measure may divert the focus of the entity's management solely to the trading function from production and the creation of value. 
Against this backdrop, it needs to be understood that the entity's owners would definitely desire to receive information enabling them to decipher the extent to which the entity's management has availed of appropriate asset replacement opportunities. Thus, the alternative valuation methods could be benchmarked against the management's asset replacement decision.

Let us, now, examine the interplay between the exit and entry valuations of an asset. A decision to replace an asset, presently optimally used by the entity, shall be made only if the entry valuation of the services being provided by the asset is less than the exit valuation of the asset providing such services. For assets providing only one service, this situation is unlikely to arise in perfect markets because, in such instances, entities would immediately replace and sell until the values are realigned. Nevertheless, such a scenario is sustainable for the assets providing more than one type of service, e.g. in the following situations, entry values could fall below the corresponding exit values when desired services are provided by a new asset, now available, more cheaply, and when the existing asset's service(s) become more valuable.

The foregoing analysis does unequivocally emphasize the fact that both valuation bases provide significantly valuable and non-overlapping pieces of information for the users of financial statements. It would, thus, be optimally sound if the management and other stakeholders could continually be made aware of both valuations of each one of the entity's assets. Financial statements may, thus, be prepared for using the measurements based on both valuation bases. This strategy would further the philosophy behind exit valuation viz. the principle of goal congruence in the construction of evaluation systems. The underlying tenet of such systems is that those actions that are most desired by evaluators viz. the entity's owners are the actions which result in the best evaluation.

We illustrate the impact of the mode of valuation on the example of the income statement and the consequential evaluation of the entity's management, by considering an asset with the following values:

\begin{tabular}{l|cc} 
& \multicolumn{2}{|c}{ Time end of the period } \\
\hline & 2 & 3 \\
Entry value & $1,300,000$ & 600,000 \\
Exit value & $1,050,000$ & 500,000
\end{tabular}

Let the income before depreciation in Period 3 be 650,000 ; then, the net income under exit value works out to $[650,000-(1,050,000-500,000)]=100,000$ while that under entry valuation is $[650,000-(1,300,000-600,000)]$ $=-50,000$. Thus, although the exit valuation vindicates the decision made by the entity's management to hold the assets at the beginning of Period 3 and continuing operations during this period, the entry valuation indicates a contrary inference. It follows that the management's performance evaluation based on the entry valuations would provide the inference that the management erred in continuing operations for the said period - it ought to have sold the asset at the beginning of the period. This inference would clearly be contraindicated if the exit valuations had been used for the asset, which would provide testimony to the veracity of the management's decision on continuing operations, at least, for the relevant period. This dichotomy in decision making may be traced to the fact that entry valuation carries the option with the management of not purchasing the asset. However, in the case of an asset already held, this option does not exist in reality, whence entry valuation is, as a matter of principle, not justified for performance evaluation because any evaluation system must be based only on the options available to the evaluatee. This problem in evaluation does not arise if exit valuation is adopted.

Nevertheless, there is an intriguing exception to the above strong advocacy of exit valuation. This arises in the case of the first accounting period, when the asset is considered for purchase. At the commencement of the first accounting period, the management does have the option of not buying the asset at the time of the initial purchase. Thus, in the context of the first 
accounting period after the asset purchase, income needs to be assessed by comparing the returns from the asset with the reduction in its entry value. If the analysis shows that the latter exceeds the former for the first accounting period, but thereafter the asset returns exceed the decline in the asset's exit valuation, the asset could be acquired (at the entry value) at the end of the first period. Thus, the cost of services in the first period would be the change between the beginning and ending entry values. In summary, then, the following appropriate reporting basis for asset valuations can be stated entry valuations for the first period, and exit valuations thereafter.

The fallout of the above-postulated scheme of valuation that needs addressing is the accounting disposition of possible differences between the entry and exit valuations of an asset at the end of the first period. In this context, the following seems to be logical:

- If exit (entry) valuation is adopted throughout, including the first period, the difference between the entry and exit values should be accounted for at the time of the purchase (disposal) of the asset. This is so because the assets valued on an entry (exit) basis will be given up (received) and the purchased (disposed) asset will be valued on an exit (entry) basis.

- However, If any mix of both exit and entry bases is adopted, the difference needs to be recognized and accounted for whenever a change in the method occurs, e.g. if the aforesaid scheme-ofvaluation mix is adopted on an entry basis for the first year and on an exit basis thereafter, the discrepancy has to be accounted for at the end of the first period.

The differences between exit and entry asset valuations, in case a combination of both bases is adopted, may be dealt with either by allocating the difference on the basis of change in exit value or entry value or the equal rate of return, or by ignoring the difference in performance evaluation relating to individual periods.
In summary, the following scheme can be presented:

- Performance evaluation for any period should be done on the valuation basis that reflects the alternatives available to the entity's management in that period;

- The difference, if any, due to the use of a (possible) mix of the valuation bases should be accounted for when the asset's life is evaluated;

- At the point in time the income from the assets shall be determined by comparing the returns generated by the assets with their net cost viz. the excess of the entry value at the time of purchase over the exit value at the time of disposal.

It needs to be emphasized once again, at the cost of being repetitive, that the preceding analysis is premised on the 'asset/liability'-based measure of income, which construes income as the accretion in value between two balance sheets, the philosophy that has regained the favor and confidence of the accounting fraternity in recent years. Nevertheless, if income is determined by the 'matching' concept, entry value tends to camouflage the effects of various external fortuitous events in the expense statement from operating income, whereas exit values tend to highlight such issues (Landsman, 2007; Magnan, 2009; Veron, 2009).

The above debate leads to the unequivocal inference that both bases of valuation have their well-defined and mutually exclusive meritorious features. As such, the financial reporting based on both valuation bases would unquestionably enhance the information content and, therefore, the utility of such statements for stakeholders and users thereof. As an alternative, 'value in use' seems to have the majority of the cardinal attributes required of a value measure. For one thing, value in use encapsulates the value of the asset in the context of the value of the entity. Furthermore, such value in use also harmoniously gels with the 'going concern' convention. Nevertheless, the use of this measure is severely constrained by the problems associated with its reliable ascertainment. Obviously, such determination entails entity-specific 
inputs, adding to the subjectivity in such calculation. However, logical considerations imply that: value in use shall be more than entry value at purchase, and value in use shall be less than exit value on disposal (Barth \& Landsman, 1995).

\section{INCOME: HICKSIAN INCOME versus FISHERIAN INCOME}

The contemporary financial accounting and reporting framework has Hicksian income as its income measure in contradistinction to Fisherian income (Rayman, 2007). We illustrate these two contrasting methodologies underlying income measurement to facilitate the understanding and appreciation of the implications thereof for financial statements by the following example:

A Ltd. is a company having a life span of $n$ years, projected to generate the free cash flows of $C_{i}$ in the year $i$ over this life span. On the basis of an assessment of the risk profile of this company and the prevalent market return rates, the appropriate riskadjusted discount rate for A Ltd. is determined as $k$ whence its fair value is calculated as:

$$
V=\sum_{i=1}^{n} C_{i}(1+k)^{-1}
$$

Let A Ltd., now, be impacted by an economic event whence its free cash flow projections are modified to $C_{i}{ }^{\prime}$ in the year $i$ together with a change in the risk profile of these cash flows, captured by the revised risk-adjusted discount rate $k^{\prime}$ whence its fair value becomes:

$$
V^{\prime}=\sum_{i=1}^{n} C_{i}^{\prime}\left(1+k^{\prime}\right)^{-1}
$$

Now, if $V^{\prime}$ exceeds $V$, there occurs an accretion in the entity's fair value. This will find its way into financial statements as a gain under the provisions of ASC 820 (FASB, 2001) or the corresponding IFRS 13 (IASB, 2012). This is in line with the Hicksian concept of income. However, the recognition of this gain may strongly violate the convention of 'conservatism', for the income so recognized may not actually have been realized at that point in time. In fact, the income may be construed to have actually been realized if, and only if, the investors of A Ltd. liquidate their investments in the entity forthwith to realize the market value of their holdings and then spend it immediately. In the event that such investors reinvest the proceeds of the sale of their holdings or equivalently, defer consumption for $m<n$ years, the market realizations of their holdings at the end of $m$ years would now be $V^{\prime}\left(1+k^{\prime}\right)^{m}$, rather than $V(1+k)^{m}$, due to the impact of the economic event. If $V^{\prime}>V$ and $k^{\prime}<k$, then $V^{\prime}\left(1+k^{\prime}\right)^{m}$ need not necessarily exceed $V(1+k)^{m}$.

There is the cutoff point:

$$
m=\frac{\log V-\log V^{\prime}}{\log (1+k)-\log \left(1+k^{\prime}\right)}
$$

at which $V^{\prime}\left(1+k^{\prime}\right)^{m}=V(1+k)^{m}$. For consumption periods shorter than this cutoff, the investor would benefit more by deferring consumption, and vice versa.

The recognition of any unrealized increase in fair value is fundamentally erroneous. This is so because any accretion in fair value that is not realized forthwith may not necessarily be translated into increased consumption power if realized at a later date. Thus, the reporting on accretion in fair value as a gain in the income statement is 'true and fair' only if all investors intend to instantly consume such accretion - a scenario grossly unrepresentative of the ground realities. In fact, this is where the merit of the Fisherian concept of income sets in.

This Hicksian concept of income (Hicks, 1946; Solomons, 1961) is not necessarily compatible with the asset/liability perspective now being advocated by the FASB and IASB. There are several reasons for this. To start with, the FASB and IASB have claimed objectivity in measurement as cardinal for shifting to the 'asset/liability' approach to income measurement. However, this claim seems implausible. There is 
unequivocal evidence that an entity's assets, other than its identifiable net assets, contribute significantly to its earning capacity. These assets, including human capital, may not be tradeable; hence, the estimation of their market values may be beset with imprecision. Thus, the incompleteness of markets, even if they are in competitive equilibrium, may generate internal goodwill, whose measurement is largely subjective, to say the least (Van Cauwenberge \& DeBeelde, 2007).

Another impediment to the adoption of the Hicksian concept of income also relates to its measurement. Hicksian income is measured not by a change in the value of the net assets of the entity, but by a change in the value of the entity itself instead. Precisely speaking, the latter represents the income of the owners of the entity, rather than that of the entity's business. Such change in the entity's value, even ex post, is primarily caused by the changed expectations of the entity's future cash flows. The change is not substantively brought about by the realized cash flows of the relevant period (Benston et al, 2006; Bromwich, 2007; Hitz, 2007; Dean, 2008; Sunder, 2008).

The adoption of the Hicksian concept of income for financial reporting also seems fallible on the grounds of making reporting fundamentally inefficacious. J. Hicks himself accepted that any practical ex post measure of income is largely irrelevant for decision making. It is conceded that reporting on such a basis can, at best, have predictive value only to the extent of providing relevant statistics. However, this may imply that decision makers, as users of such statements, may be the best persons to make, on their own, necessary adjustments in the data of past transactions so as to provide for changes in future expectations. However, if this is to be so, the option in the hands of such users of using decision support systems from within or outwith the entity, such as outputs provided by analysts, the press and academicia for ancillary and supporting inputs in lieu of adjusting financial statements may turn out to be superior on the premise that the unsubstantiated and estimated inputs of the future would not find their way into audited financial statements and reports.
The issue relating to the suitability of or otherwise to Hicksian income in the financial reporting system subsists in perfect markets as well. This is unlike several other characteristics of FVA that emanate from market imperfections.

\section{CONCLUSION}

In this paper, an attempt has made to examine several issues occupying center stage in the contemporary accounting environment viz. transition to the 'asset/liability' conceptual framework for income determination, the use of exit-based valuation in measuring the 'fair value' of assets and liabilities, and the adoption of the Hicksian measure of income. Various implications of these aspects have been assessed and reported. The antagonists of the current accounting paradigm are likely to strongly espouse their concerns on these lines. The incumbent analysis highlights the cardinal issues that warrant serious discussion and debate among the accounting fraternity. It is universally accepted that accounting information needs to be significantly relevant for use in the user's decision making processes. The contentions raised herein tend to dilute this relevance of financial reporting for end users.

The analysis of the pronouncements of the regulatory bodies together with the review of the relevant literature presented in this work unequivocally reject the null hypotheses set up, leading to the acceptance of the 'alternative' hypotheses viz.

H1: The 'asset/liability' conceptual framework recommended by the FASB and IASB does not invariably correctly report the financial affairs of an entity.

H2: The exit-based valuation adopted by the FASB and IASB in the definition of the 'fair value' of assets and liabilities is not the appropriate accounting measure of 'fair value' in all circumstances. 
H3: The 'Hicksian' concept of income adopted by the FASB and IASB, in conjunction with the 'asset/liability' framework, is not essentially the appropriate accounting measure of income.

It must, however, be emphatically underscored that this is purely a theoretical study. Although the findings seem to be unequivocal, the study carries the author's perceptions, views, skill and understanding and interpretations as its main limitation. There is, therefore, a possibility that the inferences of the study could be influenced by such perceptions, biases and interpretations. This observation opens up vistas for future research. Empirical studies may be undertaken to corroborate and validate these findings. Ideally, conceptual inferences should invariably be validated by empirical studies for trustworthy inference. However, the inferences obtained through statistical analysis may also need to be accepted with caution, howsoever sophisticated these tools may be. Besides, the studies that explore the various issues relating to human decision making have certain intrinsic limitations. There is no mathematical framework that can model such decision making processes quantitatively in all their degrees of freedom. Any quantitative model invariably involves the truncation of the system space by a reduction in the number of the degrees of freedom that can be tracked. This causes fuzziness in system modeling with a loss of information. Consequently, it becomes impossible to frame the set of the evolution equations that could possibly lead to an exact mathematical solution to such problems.

In addition to the possibility of taking up empirical studies in order to validate the findings herein, research programs need to be taken up by professional accounting bodies and practitioners' forums so as to identify, develop and formulate a conceptually superior accounting framework that cuts through the ambiguities created by the issues presented herein. Medium-term research that explores further shortcomings/limitations of the contemporary framework in its current applications or identifies further sectors/areas which could be targeted in order to improve the quality of financial reporting could also be contemplated.

However, it does seem that the conceptual framework presently propounded by the FASB and IASB may not be able to dispense with either of the two issues highlighted in this article viz. the use of exit valuation together with the Hicksian concept of income forthwith, although the shift of emphasis to the 'asset/liability'-based conceptual framework is clearly discernible except, possibly, in a few cases where the revenue/expense model is retained for the reason of its being more representative of the maintainable earnings concept. There is some indication of a review of this movement by the FASB and IASB in their Revenue Recognition and Fair Value Projects. It is important to emphasize at this point that the issues raised herein can also be sourced to the well-entrenched conventions that form the backbone of business performance appraisal. Although these conventions may lack scientific and/ or rational underpinnings, yet their existence and role in accounting practice cannot be disputed. Thus, for a cohesive accounting framework/model, the interrelationships between concepts and conventions need to be embedded therein. Merely the adoption of Hicksian income as a measure neither implies nor is implied by an exclusive asset/liability-based income determination, nor does it facilitate the use of ex post financial reporting for assessing business performance. The 'objectivity' and 'unambiguity' of Hicksian income for financial reporting, so claimed by the FASB and IASB, seems to be substantively overstated. However, notwithstanding the flaws embedded in the conceptual underpinnings of FVA, as espoused hereinbefore, its gradual, but rapid, acceptability and adoption among standard setters is unequivocally welcome - it represents a paradigm shift in emphasis among the accounting fraternity towards the 'relevance' of financial reporting to the users thereof. An encouraging start to ushering in the era of 'fair value accounting' has been made. Understandably, some critical aspects need addressing, but these represent evolutionary glitches, rather than catastrophic mis-endeavors. FVA is 
widely being viewed as an integral constituent of the regulator's toolbox for ushering in an efficacious suite of upgradations for user-friendly financial reporting. There seems to be little doubt that the philosophy of fair value accounting is here to stay and should be fostered by all its votaries.

\section{REFERENCES}

American Accounting Association's Financial Accounting Standards Committee. (2007). The FASB's conceptual framework for financial reporting: A critical analysis. Accounting Horizons, 21(2), 229-238. doi.org/10.2308/ acch.2007.21.2.229

American Accounting Association's Financial Accounting Standards Committee. Ohlson, J. A., Penman, S., Bloomfield, R., Christensen, T. E., Colson, R., Jamal, K., Moehrle, St., Previts, G., Stober, T., Sunder, S., \& Watts, R. L. (2010). A framework for financial reporting standards: Issues and a suggested model. Accounting Horizons, 24(3), 471-485. doi. org/10.2308/acch.2010.24.3.471

Barth, M. E. (2007). Standard setting measurement issues and the relevance of research. Accounting and Business Research, Special Issue, 7(1), doi.org/10.1080/00014788.2007.9730079

Barth, M. E., \& Landsman, W. R. (1995). Fundamental issues relating to using fair value accounting for financial reporting. Accounting Horizons, 9(4), 97-107.

Benston, G. J. (2006). Fair-value accounting: A cautionary tale from Enron. Journal of Accounting and Public Policy, 25(4), 465-484. doi.org/10.1016/j.jaccpubpol.2006.05.003

Benston, G. J. (2008). The shortcomings of fair value accounting described in SFAS 157. Journal of Accounting and Public Policy, 27(2), 101-114. doi.org/10.1016/j.jaccpubpol.2008.01.001

Benston, G. J., Bromwich, M., \& Wagenhofer, A. (2006). Principles- versus rules based accounting standards: The FASB's standard setting strategy. ABACUS, 42(2), 165-188. doi: 10.1111/j.1467-6281.2006.00196.x
Boulton, R. E. S., Libert, B. D., \& Samek, S. M. (2000). Cracking the Value Code: How Successful Businesses are Creating Wealth in the New Economy. New York, NY: HarperBusiness.

Bromwich, M. (1992). Financial Reporting, Information and Capital Markets. London, UK: Pitman.

Bromwich, M. (2001). The ACCA/BAA distinguished academic 1999 lecture- angels and trolls: The ASB's statement of principles for financial reporting. The British Accounting Review, 33(1), 47-72. doi.org/10.1006/bare.2000.0150

Bromwich, M. (2007). Fair values: imaginary prices and mystical markets. In P. J. Walton (Ed.). The Routledge Companion to Fair Value and Financial Reporting. London, UK: Routledge.

Chabrow, E., \& Colkin, E. (2002). Information Week.

Christensen, J. A. (2010). How do conceptual frameworks contribute to the quality of corporate reporting regulation? Accounting and Business Research Special Issue: International Accounting Policy Forum.

Christensen, J. A., \& Demski, J. S. (2003). Accounting Theory. An Information Content Perspective. New York, NY: McGrawHill.

Dean, G. W., \& Clarke, F. L. (2003). An Evolving Conceptual Framework. ABACUS, 39(3), 279-297. doi: 10.1111/j.14676281.2003.00133.x

Dean, G. W. (2008). Editorial: Conceptual Frameworks, Fair Value Measurement and Decision Making. ABACUS, 44(3), I-VII. doi: 10.1111/j.1467-6281.2008.00260.x

Dennis, I. (2006). Here We Go Again ..., Oxford Brookes University Working Paper, available as Comment Letter \#50 on the IASB/FASB project website: http://www.iasb.org/NR/ rdonlyres/2D4D6717-557F-47AA-8BB2-A22E6FCCADF0/0/ CL50.pdf

Dennis, I. (2008). A conceptual enquiry into the concept of a "principles-based” accounting standard. The British Accounting Review, 40(3), 260-271. doi.org/10.1016/j. bar.2008.05.005 
Eccles, R. G., Herz, R. H., Keegan, E. M., \& Philips, D. M. H. (2001). The Value Reporting Revolution: Moving Beyond the Earnings Game. New York, NY: John Wiley.

Eckstein, C. (2004). The measurement and recognition of intangible assets: Then and now. Accounting Forum, 28(2), 139-158. doi.org/10.1016/j.accfor.2004.02.001

Financial Accounting Standards Board. (2000). Financial Accounting Standard 133. Accounting for Derivatives and Hedging Activities, USA.

Financial Accounting Standards Board. (2001). Financial Accounting Standard 141. Business Combinations, USA.

Financial Accounting Standards Board. (2001). Financial Accounting Standard 142. Goodwill and Other Intangible Assets, USA.

Financial Accounting Standards Board. (2001). Financial Accounting Standard 157. Fair Value Measurements. USA.

Financial Accounting Standards Board. (2009). Accounting Standards Code 820. Fair Value Measurements. USA.

Gwilliam, D., \& Jackson, R. H. G. (2008). Fair value in financial reporting: problems and pitfalls in practice. Accounting Forum, 32(3), 240-259. doi.org/10.1016/j.accfor.2008.01.003

Hicks, J. R. (1946). Value and Capital. Oxford, Clarendon Press.

Hitz, J. M. (2007). The decision usefulness of fair value accounting - A theoretical perspective. European Accounting Review, 16(2), 323-362. doi.org/10.1080/09638180701390974

International Accounting Standards Board. (2012). International Financial Reporting Standard 13, Fair Value Measurements.

Landsman, W. R. (2007). Is fair value accounting information relevant and reliable? Evidence from capital markets. Accounting and Business Research, 37(1), 19-30. doi.org/10.1080 /00014788.2007.9730081

Lev, B. (2001). Intangibles: Management, Measurement and Reporting. Brookings Institution Press.

Magnan, M. (2009). Fair value accounting and the financial crisis: Messenger og contributor? Accounting Perspectives, 8(3), 189-213. doi: 10.1506/ap.8.3.1
Nissin, D., \& Penman, S. (2008). Principles for the application of fair value accounting. White Paper No. 2, Columbia Business School.

Penno, M. C. (2008). Rules and accounting: Vagueness in conceptual frameworks. Accounting Horizons, 22(3), 339-351. doi.org/10.2308/acch.2008.22.3.339

Potter, B. (2005). Accounting as a social and institutional practice: Perspectives to enrich our understanding of accounting change. ABACUS, 41(3), 265-289. doi: 10.1111/j.1467-6281.2005.00182.x

Rayman, R. A. (2006). Accounting Standards: True or False? Routledge.

Raymen, R. A. (2007). Fair value accounting and the present value fallacy: the need for an alternative conceptual framework. The British Accounting Review, 39(3), 211-225. doi. org/10.1016/j.bar.2007.03.006

Solomons, D. (1961). Economic and accounting concepts of income. The Accounting Review, 36(3), 374-383.

Sundem, G. L. (2007). A Note on the Information Perspective and the Conceptual Framework. In R. Antle, F. Gjesdal, \& P. J. Liang (Eds.), Essays in Accounting Theory in Honour of Joel S. Demski (pp. 285-293). New York, NY: Springer.

Sunder, S. (1997). Theory of Accounting and Control. Cincinnati, $\mathrm{OH}$ : South-Western.

Sunder, S. (2008). Econometrics of Fair Values. Accounting Horizons, 22(1), 111-125. doi: doi.org/10.2308/ acch.2008.22.1.111

Uzma, S. H., \& Singh, J. P. (2009a). Intangibles accounting Issues \& dimensions. The Accounting World, 19.

Uzma, S. H., \& Singh, J. P. (2009b). Brand Recognition: The Contemporary Scenario. Chartered Secretary.

Veron, N. (2009). Fair value accounting is the wrong scapegoat for the crisis. European Accounting Review, 5(2), 63-69. doi. org/10.1080/17449480802510542

Van Cauwenberge, P., \& DeBeelde, I. (2007). On the IASB comprehensive income project: an analysis of the case for dual income display. ABACUS, 43(1), 1-26. doi: 10.1111/j.1467-6281.2007.00215.x 
Watts, R. (2003a). Conservatism in accounting Part I: Wells, M. (2003). Forum: The Accounting Conceptual Explanations and implications. Accounting Horizons, 17(3), Framework. Introduction. ABACUS, 39(3), 273-278. doi: 207-221. doi.org/10.2308/acch.2003.17.3.207 10.1111/j.1467-6281.2003.00132.x

Watts, R. (2003b). Conservatism in accounting Part II: Evidence and research opportunities. Accounting Horizons, 17(4), 287301. doi.org/10.2308/acch.2003.17.4.287

Whittington, G. (2008). Fair Value and the IASB/FASB Conceptual Framework Project: An Alternative View. ABACUS, 44(2), 139-168. doi: 10.1111/j.1467-6281.2008.00255.x

\section{Received on $20^{\text {th }}$ December 2016, after one revision, accepted for publication on $24^{\text {th }}$ April 2017 \\ Published online on $28^{\text {th }}$ April 2017.}

Jatinder Pal Singh, PhD, is a Professor at the Indian Institute of Technology Roorkee and a professional member of the Institute of Chartered Accountants of India, Institute of Cost Accountants of India, Institute of Company Secretaries of India and Institution of Engineers (India). His research interests are in econophysics, mathematical finance, financial risk management, international finance and corporate governance. 


\title{
O KONCEPTUALNIM TEMELJIMA RAČUNOVODSTVA ZASNOVANOG NA PRAVIČNOJ VREDNOSTI
}

\author{
Jatinder P. Singh \\ Department of Management Studies, Indian Institute of Technology Roorkee, Uttarakhand, India
}

Poslovni procesi i korporativne strategije se na globalnom nivou brzo preobražavaju. Kritičnoj ulozi nematerijalne imovine u poslovanju privrednih društava posvećuje se odgovarajuća pažnja. Složeni finansijski proizvodi kojima se može trgovati preplavljuju finansijska tržišta. U nastojanjima da se pripreme za suočavanje sa izazovom koji pred njih stavlja finansijsko izveštavanje u okruženju, donosioci standarda su izvršili suštinsko restrukturiranje sistema za izveštavanje, sa "pravičnom vrednošću“ kao temeljom tih sistema. U objavama i tekućim projektima američkog Odbora za standarde finansijskog računovodstva (FASB) i Odbora za međunarodne računovodstvene standarde (IASB) uočavaju se distanciranje od tradicionalnog načina merenja prihoda, koje počiva na uparivanju "prihoda i troškova“, i okretanje ka merenju odnosa "aktive i pasive“, uz istovremeno usvajanje Hiksovog koncepta prihoda. U radu su analizirana kontroverzna pitanja koja zahtevaju jasniju formulaciju, u meri u kojoj se ta pitanja odnose na računovodstvo zasnovano na pravičnoj vrednosti.

Ključne reči: pravična vrednost, finansijsko računovodstvo, „,izlazna“ i „ulazna“ vrednost, prihod, konceptualni okvir, FASB, IASB, merenje odnosa aktive i pasive

JEL Classification: G30, M41, N30 